\title{
Tropical Imaginaries and Climate Crisis: Embracing Relational Climate Discourses
}

\author{
Anita Lundberg \\ https://orcid.org/0000-0002-0271-4715 \\ James Cook University, Australia \\ André Vasques Vital \\ https://orcid.org/0000-0002-6959-3196 \\ Evangelical University of Goiás, Brazil \\ Shruti Das \\ https://orcid.org/0000-0002-6148-1093 \\ Berhampur University, Odisha, India
}

\begin{abstract}
In this Introduction we situate the Special Issue on 'Tropical Imaginaries and Climate Crisis' within the context of a call for relational climate discourses as they arise from particular locations in the tropics. Although climate change is global, it is not experienced everywhere the same and has pronounced effects in the tropics. This is also the region that experienced the ravages to humans and environments - of colonialism. It is the region of the planet's greatest biodiversity; and will experience the largest extinction losses. We advocate that climate science requires climate imagination - and specifically a tropical imagination - to bring science systems into relation with the human, cultural, social and natural. In short, this Special Issue contributes to calls to humanise climate change. Yet this is not to place the human at the centre of climate stories, rather we embrace more-than-human worlds and the expansion of relational ways of knowing and being. This paper outlines notions of tropicality and rhizomatics that are pertinent to relational discourses, and introduces the twelve papers - articles, essays and speculative fiction pieces - that give voice to tropical imaginaries and climate change in the tropics.
\end{abstract}

Keywords: tropical imaginary, climate imaginary, climate crisis, Tropics, climate change, rhizomatics, tropicality, relational, more-than-human worlds

eTropic: electronic journal of studies in the tropics publishes new research from arts, humanities, social sciences and allied fields on the variety and interrelatedness of nature, culture, and society in the tropics. Published by James Cook University, a leading research institution on critical issues facing the world's Tropics. Free open access, Scopus Listed, Scimago Q1. Indexed in: Google Scholar, DOAJ, Crossref, Ulrich's, SHERPA/RoMEO, Pandora. ISSN 1448-2940. Creative Commons CC BY 4.0 free to download, save and reproduce. To cite, include: Author(s), Title of Paper, Editors (Eds.) Special Issue Title (Special Issue) eTropic, volume, issue, year, pages and DOI: http://dx.doi.org/10.25120/etropic.20.2.2021.3803 


\section{Entrée: Into the Tropics}

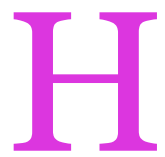
eat waves and wave-inundated islands, prolonged droughts and rainforest fires, tropical storms and monsoon deluges, melting glaciers and flooded rivers - although climate change is global, it is not experienced everywhere the same. Climate change has pronounced effects in the Tropics.

Human caused global warming of the atmosphere, land and ocean, has been confirmed with 'unequivocal' certainty (IPCC, 2021, A.1). It is also confirmed that climate systems become greater "in direct relation to increasing global warming." Which includes "increases in the frequency and intensity of hot extremes, marine heatwaves, and heavy precipitation, agricultural and ecological droughts in some regions" and the "proportion of intense tropical cyclones" (IPCC, 2021, B.2). Global sea level rise has also been reported with 'certainty'.

However, relative sea level rise, along with other climate change effects, is predicted to be higher in the Tropics. The melting of the Greenland and the Antarctic ice sheets creates a dynamic where reduced gravitational attraction close to melting ice sheets in the Polar regions causes local sea level fall, while substantially increasing sea level rise farther from the ice sheets in the equatorial Tropics (IPPC, 2021, TS-45; Lundberg, 2021). While ice sheet melt is the main source of rising sea levels, oceans also absorb excess atmospheric heat which results in thermal seawater expansion.

Ocean warming further impacts the atmospheric systems of the Indian Ocean Dipole (IOD) and the EI Niño-Southern Oscillation (ENSO), which causes EI Niño and La Niña events. The predicted increase in intensities and frequencies of these regional atmospheric-oceanic phenomena will have far reaching effects on weather patterns throughout the tropics and subtropics - causing extended drought in some regions and extreme rainfall in others (Lundberg, 2021). Global warming also increases intensities of oceanic-atmospheric events which cause tropical storms (see Albino, 2021, this issue). Locally called 'cyclone' in the Indian Ocean and South Pacific, 'hurricane' in the Western Atlantic, Caribbean Sea, and Eastern Pacific, and 'typhoon' in the Western Pacific, the reach of tropical storms is extending further poleward into the temperate northern and southern zones with global warming. While tropical storm intensities are extending, sea level rise will, in turn, increase storm surge levels and flooding of coastal areas.

While oceans, along with rainforests, tropical peat swamps and mangroves, are major carbon dioxide sinks, global warming means these sinks can reach saturation and begin to emit sequestered carbon dioxide back into the atmosphere - adding to, rather than reducing, global warming. Coral reefs, rainforests, and mangroves are incredible 
tropical biodiverse ecosystems which have developed over thousands of years: however, ocean warming, sea level rise, and acidification, bleach and kill protective coral reefs; while deforestation and fires add greenhouse gases to the atmosphere. The Tropics - which has long been imagined through visions of rampant jungle entanglements has become a critical zone of cascading tipping points, the site where the full scale and scope of climate change and its associated challenges and deathly consequences are becoming materially manifest.

This year marks the long-awaited United Nations Climate Change conference. The agenda includes the $26^{\text {th }}$ Conference of the Parties (COP26) to the United Nations Framework Convention on Climate Change (UNFCCC). Following the Paris Agreement and the Kyoto Protocol, the conference aims to commit nations to a revitalized effort to urgently reduce anthropogenic carbon dioxide to net zero emissions in order to limit global warming at $1.5^{\circ} \mathrm{C}$. While acknowledging the importance of the UN Climate Change global agenda, this Special Issue draws attention to the tropical regions of the world: regions that are undergoing rapid development, yet suffer serious poverty; hold the planet's greatest biodiversity; and will experience the largest extinction losses (see Sodikoff, 2021, this issue); are home to many of the world's rainforest, mangrove, and maritime peoples, but endure legacies of colonialism and the increasing manoeuvres of neo-colonialism. In this Special Issue we advocate that climate science requires climate imagination to bring science systems into relation with the human, the social, the cultural and material (see Kandolkar, 2021, this issue). In short, this issue contributes to calls to humanise climate change discourses. However, this is not to put humans at the centre of the climate story; rather it is to engage the anthrōpos (human), within more-than-human worlds - to entangle us in the world with atmospheres, oceans, plants, animals, microbes (see Chao \& Enari, 2021, this issue).

To perceive the vast intricacies involved in climate change phenomena requires imagination; a poetics of thought. Tropical imagination as expressed in this Special Issue collection is informed by Indigenous knowing, vernacular knowledge, ethnography, patchy Anthropocene, Plantationocene, Chthulucene, phenomenology, more-than-human worlds, rhizomatics, material culture and material poetics, archipelagic imaginaries, ecocriticism, ecofeminism, postcolonialism, and tropical climate change storying, including through literature, mythologies, comics, climate fiction (cli-fi), speculative fiction and hybrid memoir.

The Special Issue brings together a wide range of articles, essays and literary works from researchers who engage with the tropical regions of the planet. Thus, these papers are also bound up in the long histories of how the tropics have been imaginatively constructed. 


\section{Tropicality}

The notion of tropical and the tropics are factually and imaginatively multidimensional. While the tropical has a propensity to be defined in geographical terms - the Tropics as the band around the Earth extending from the equator out to the Tropic of Cancer and the Tropic of Capricorn - this reduction of the tropics to latitudes does not adequately describe the sense of the tropical.

Human and cultural geographers have more recently revealed how the tropics is an imagined geography - a space conceived through a Western imperial lens. The term 'tropicality' gives a sense of this complex phenomenon. As Dan Clayton articulates:

Tropicality is the age-old discourse (or suite of ideas, experiences, sensations and representations) through which 'the West' regards itself as 'temperate' (moderate, secure, comfortable, self-controlled and staid) and 'the tropics' as alien and its opposite (a domain of allure, seduction, danger, riot and excess). This temperate/tropical opposition has been conceived foremost in environmental terms, historically through capitalist and colonialist expansion and exploitation, and with factors of climate and disease...paramount. Tropicality helped to produce empire and buttress Western ideas of dominance and superiority. But it has outlived the age of European colonial empires and continues to shape and split 'global' understanding and experience (Clayton, 2021, p.55)

The concept of tropicality, similar to Edward Said's seminal work on Orientalism (1978), asks us to analyse the ways in which the tropics have been intimately imagined through multiple discourses. Or, as Clayton explains: "constructed - viewed, encountered, invented, coveted, and controlled - by Western travellers, scientists, settlers, soldiers and traders as they explored and moved into tropical regions and derived a set of 'temperate' values and 'tropical' vistas from their experiences" (2021, p.56). While tropicality has been constructed through these imperialist renderings, it also has more ancient pre-conceptions, going back to 320 BCE and Aristotle's notion of the torrid zone as uninhabitable to humans.

The imagining and construction of the tropics through a temperate imperialist gaze was well understood by the Caribbean poet, author and politician Aimé Césaire. Conceived through experiences of his native Martinique, Césaire used the term tropicalité as an anti-colonial concept that subverted and reverted the colonial agenda (see also, Lacuna, 2021, this issue). 
As Clayton explains:

Césaire saw 'the tropics' as a scene par excellence not only of colonial rapacity but also of how the violence embedded in a host of oppositions - between the usual and strange, normal and pathological, moderate and excessive, refined and gaudy, hallowed and plagued, immune and susceptible, hospitable and inhospitable, resplendent and insipid, and vigorous and languid - had been disguised and deflected. (Clayton, 2021, p.58)

The colonial roots of tropicality have been significantly addressed in many publications of the Singapore Journal of Tropical Geography, including Victor Savage's paper 'Tropicality Imagined and Experienced' (2004) which offers a clear entrée into the concept. However, it is important to note that tropicality has not disappeared with postcolonialism and the turn to discourses of globalisation - which are also embedded in the phrase 'global climate change'.

As James Sidaway, Chin Yuan Woon and Jane M. Jacobs in 'Planetary Postcolonialism' (2014) advise, postcolonialism and new forms of transnational imperialisms are rooted in notions of globalisation. Thus, while many theorists in the social sciences have adopted globalisation to imagine the world, in the humanities, some theorists believe that the 'planetary' offers a richer way in which to understand the world. The authors note that Gayatri Chakravorty Spivak proposes 'the planet' over 'the globe'. For while globalisation renders the same system everywhere, an "abstract ball covered in latitudes and longitudes, cut by virtual lines", the "planet is a species of alterity" (Spivak, 2003, quoted in Sidaway et al., 2014, p. 5).

The authors argue that Spivak ruptures the taken for granted imaginary of the 'global' and returns us to its colonial genealogy. Venturing into this background they further remind us of how "imperialism has always been an ecological project, in which humans, plants and other species were shifted around the earth in schemes for colonization/conservation" (Sidaway et al. 2014, p.5). In the current age, they note that globalisation is also at the heart of the concept of the Anthropocene. However, even as the Anthropocene firmly acknowledges human activity as the dominant agent of climate change, the concept simultaneously internalizes an imaginary of the globe and the environment conceived through a Western scientific worldview.

The term lends itself to conceiving of the planet and humans as homogenous. In order to counter this simplification, anthropology has engaged the notion of patchy Anthropocene to reveal fragmented landscapes of ruin wrought by colonialism and industrialization (see Das \& Routray, 2021, this issue). Taking these fragmented 
landscapes a step further, the interdisciplinary team of Anna Tsing, Jennifer Deger, Alder Keleman Saxena and Feifei Zhou, in Feral Atlas - The More-Than-Human Anthropocene (2021), have begun to trace landscapes whose ecologies sprout from human built infrastructure and spill beyond human control, going feral. In turn, Donna Haraway (2015), the feminist science and technology studies scholar, has suggested using the term Anthropocene critically, along with other terms, including Plantationocene (see Jerez Colombié, 2021, this issue) and Chthulucene (see Boswell, 2021, this issue), in order to retain critical awareness of local manifestations of human induced environmental and climatic crises.

This Special Issue advocates the need for situated analyses within the global climate change discourse at the level of elements, humans and places. We remain aware that even carbon dioxide is "produced in particular places and travels, with local results" (Tsing et al., 2021). We remember that Chakrabarty has declared that, "the crisis of climate change will be routed through our "anthropological differences"' (Sidaway et al. 2014, p.5). And, we add, that climate change will manifest unevenly within specific human geographies.

The two terms 'Tropical Imaginary' and 'Climate Crisis', that frame and inspire this Special Issue likewise manifest in various ways influenced by cultural, geographical and disciplinary-interdisciplinary perspectives. Here we offer a rumination on 'Tropical Imaginaries' (see also Benitez, 2021, this issue) from an ecocritical-postcolonial perspective with examples drawn from literature and climate in India (see also Lacuna, 2021, this issue, re Philippines); followed by a deep reflection on 'Climate Crisis' from a science, technology and environment perspective illustrated through examples from animation and climate in Brazil.

\section{Tropical Imaginaries}

In one imaginary, the Tropics is rendered as a geographic space of beauty, where it is warm and humid, with modest variations in temperature throughout the year, and thus host to the most exotic flora and fauna. Yet, the Tropics is also the food belt of the world where the warm wet climate is conducive to the growth and production of many varieties of food crops like sugarcane, rice, sweet potatoes, soya bean, banana, mangoes, cocoa, coffee and tea. With the advent of colonialism, capitalist machineries started operating and exploiting the region and denuding it of its rich flora, fauna and other natural resources, including minerals - as well as decimating the original inhabitants of the region. Colonial capitalist machineries operated at local levels and accelerated the global natural resource crisis. The environmental concerns of the people living in the tropics, who are economically, politically, culturally, and even, geographically marginalized due to capitalist colonial invasions, are quite different 
from those of the developed world (see also, Hartnett, 2021, this issue). Scott Slovic, Swarnalatha Rangarajan and Vidya Sarveswaran (2015) note that the Global South which is primarily comprised of tropical countries - "takes on the task of articulating the socio-ecological plight of the world's poor by drawing attention to the fact that the uneven patterns of neoliberal development in the Global South threaten the millions who depend upon access to natural resources for their survival"(2015, p. 3). Amitav Ghosh (2016) believes that capitalism is the pivot on which the narrative of climate crisis turns. He further states that this narrative of capitalism "often overlooks an aspect of global warming that is of equal importance: empire and imperialism.... To look at the climate crisis through the prism of empire is to recognize, first, that the continent of Asia is conceptually critical to every aspect of global warming: its causes, its philosophical and historical implications, and to the possibility of a global response to it" (pp. 117-118). The demand for rightful living and a healthy life of the impoverished people is ignored and the looming problem of resource depletion underlines the discourse of the "environmental justice that has moved ecocriticism to consider how disenfranchised or impoverished populations the world over face particular environmental problems" (Roos \& Hunt, 2010, p. 7). The actual environmental problems reside in depletion of resources which in turn lead to climate change and go hand in hand with denial of justice to local populations. India is one such country that has suffered from both colonial onslaught and neo-imperial capital hegemony. Pankaj Shekhsaria describes the condition of the India united territories of Andaman and Nicobar Islands under colonization and capitalist invasion in his books The Last wave: An Island Novel (2014) and Island in Flux: The Andaman and Nicobar Story (2017). Imperialism and capitalist invasion have corroded and thereby changed the face of the Andaman and Nicobar Islands, a territory which was once extensively covered in rainforests and supported a rich variety of flora, including 200 endemic species, as well as fauna including land animals, birds and butterflies, and aquatic treasures. The islands were also home to indigenous Andamanese peoples and Austroasiatic Nicobarese peoples. Sekhsaria notes that a Jarawa tribal reserve was finally established by the Government of India in 1957 with an objective to protect the Jarawa (one of the endangered tribes of the Andamans) inside the $1000 \mathrm{~km}^{2}$ reserve and to prevent settlers from encroaching upon it: "Today, there are only about 250 of them and vast expanses of their rainforest homelands have been cleared to accommodate settlers and to feed the huge timber industry on which rests the economic foundation of the Andamans" (2017, p. 60). Sekhsaria explains how deforestation breaks the water cycle which is crucial for existence of life and describes how Baratang, a settlement in the Andaman Islands, "is like a furnace, and the villagers there have a serious water problem. It's not just the forests that suffer, people do too - the entire hydrology of the area changes" (2014, p.189). The situation on the territory of the Andaman and Nicobar islands supports Vandana Shiva's observation that "The drying 
up of India, like that of Africa, is a man-made rather than a natural disaster" (1988, p. 171).

Dipesh Chakrabarty in his essay 'Climate of History: Four Theses' published in Critical Inquiry in the winter of 2009 links the crisis of climate change to governmental neglect, capitalist lies and denial, and more importantly the disconnect and indifference of the actual stakeholders. Environmental critics like Scot Slovic, Promod Nayar, Susanna Priest and others have felt that the climate crisis has traditionally been addressed by scientists, economists, politicians and the media, which overpowers dialogues at social levels. Priest (2016) believes that "climate crisis is something of a communication emergency" (p. 9) which should be addressed as a priority so that climate change discourse can be transformed and people can engage constructively with the reality of the crisis. Scot Slovic (2005) also emphasizes the role of language, especially literature, in addressing the vital issue of climate change. Yet, we note that: "Ordinary language would be inadequate to articulate such complex and politically coloured situations. Therefore, myths and metaphors that cannot be evaluated in terms of truth conditions are often used by writers to throw light on the vital problem of anthropogenic climate change and Earth's ecological distress" (Das, 2020, p. 71-77).

In the last few decades the world has suffered from acute climate change induced conditions with warming temperatures that affect high mountain glaciers, as well as rising sea levels that inundate low deltaic plains. We have experienced severe storms, excessive cloudbursts and flash floods. These seem uncanny and beyond the comprehension of the ordinary human.

The Churabaari Glacier in the Himalayas of the Northern Indian State of Uttarakhand, is the source of the Mandakini River which merges with other river systems, flows past the $8^{\text {th }}$ century Kedarnath pilgrimage shrine to Lord Shiva, and eventually drains into the great Ganges River to be dispersed across the fertile deltaic plain of IndiaBangladesh and finally meets the sea the Bay of Bengal. On the 16-17 th of June 2013, the river Mandakini experienced a massive flash flood, induced by extreme rainfall $375 \%$ above the monsoon average. The rain caused melting of glacier ice and broke the banks of the glacier lake. It wrought unprecedented havoc in Uttarakhand destroying everything in its path: houses, bridges, dams and the town of Kedarnath and Rambara (Joshi, 2016). Thousands died in the flood and consequent landslides, including locals and pilgrims; of those who lived, many lost their homes and livelihoods. The disaster was so sudden and its dimensions so vast that people are still unable to comprehend it. The fear and the trauma of this eco-disaster would have been gradually forgotten as an uncanny event had Hridayesh Joshi not documented it in the form of stories (also see Nakai, 2021, this issue). The ecological uncanny generated in the sites of eco-disasters tempt humans to imagine the ghostly, the mythic, the alien, the familiar and the strange in order to make some sort of meaning 
of the disaster. Pramod K. Nayar (2017) contends that literary texts are the only means of delivering the urgent news of climate change, eco-disaster and the fragility of human-nature relations.

\section{Climate Crisis}

In 2011, the Brazilian animated short film O Diário da Terra (Earth's Diary), directed by Diogo Viegas, was released. In just over a minute of animation a girl narrates how climate change is affecting her life. A fan of winter, she can no longer go out to play in the snow as before, due to the extreme cold in recent years. A lover of sunbathing on the beach during the summer, she finds herself equally limited due to the higher incidence of days of heavy rains with winds strong enough to drag away people (reminding us of hurricanes). Both situations illustrate the extremes of weather provoked by climate change on the entire planet (from extreme winters of temperate zones to monsoonal tropical summers). The girl's diary contends that humans are destroying this planet, and the pages of her diary - narrated in her sweet childish voice - show images of factories, deforestation and setting land on fire. The character of the planet, with its sad countenance, reinforces this classic notion of the finiteness of the natural resources of the Earth and leaves the viewer with a sense that this is our world, made for us, and managed or mismanaged by us - a classical environmental notion. However, in the last scene, the girl narrates how one day when the page of her diary is turned, it will be the last page of Earth's diary. And her words are reinforced by the flashing of empty pages. The abrupt end leaves a gloomy atmosphere of a world without us (see Weisman, 2007; Thacker, 2011, p. 14). The allusion of an end to humanity, ruptures the environmental storyline, and is followed by the eloquent silence of the movie credits. Horror is present in this end, a contingency suggesting the possibility of self-annihilation.

Animations are anchored in broad political, social, cultural and environmental contexts that, while questioning reality through their subversion, also expose the fears and anxieties of the period in which they are produced (Wells, 1998). Animations of the environmental genre, through imagined scenarios, produce knowledge and subjectivities anchored in the environment as a subject, problematising and speculating about the future of the planet (Starosielski, 2011). If, on the one hand, the emphasis on nature as a harmonic whole in danger, and lacking in humans engaged in its salvation, was strongly present in animations of the 1970s; there are currently animations where non-humans are presented and the emphasis is on the multiplicity of forms of existence which emerge though a threatening dimension, evasive to thought and, therefore, inducing uncertainties and ruptures (see Vital, 2018; Vital, 2019). The mere suggestion of the end of the world as an end of humanity in an 
environmental animation such as O Diário da Terra, is a symptom of the anxieties and the climate of uncertainty emanating from the multiplicity of unprecedented phenomena related to the climate crisis that permeates the tropics.

Unprecedented phenomena are found in what the historian Zoltán Simon (2021) refers to as inducing 'evental' historical transformations, that is, disruptive events that produce ruptures (Simon, 2021, p. 149). However, being contingencies, they are simultaneously within the scope of possible persistence (continuity) and possible expiration (rupture); they are - as in the definition of contingency set forth by Quentin Meillassoux (2008, p. 62-63) - a pure possibility that may or may not happen. They are thus contingent events not only through producing ruptures, indicating the precariousness of human and non-human things; but through feeding feelings and thoughts about multiple possibilities (which include the annihilation of human life as we know it). Some of these phenomena, widely reported by the media, illustrate the concrete circumstances in which these feelings and thoughts emerge.

Up until February 2004, it would have been absurd to talk about the possibility of hurricanes in the southern hemisphere of the Atlantic Ocean. However, on March 24, 2004, what was an extra-tropical storm became the first tropical cyclone recorded in the South Atlantic. Catarina (also called Aldonça and 50L), a tropical storm system with an intensity similar to that of a Category 2 hurricane on the Saffir-Simpson scale, struck the State of Santa Catarina, Brazil. As an unprecedented event, Catarina produced numerous ruptures and uncertainties. The predictive models largely failed: most of them underestimated the intensity of the storm when reaching the Brazilian coast and the system followed a consistently linear trajectory, both in terms of intensity and direction (something considered unusual for such a dynamic system). Finally, Catarina raised an intense scientific controversy in the international community, with Brazilian meteorologists arguing that it was not a hurricane, as US scientists had immediately identified it as, but a "rare cyclone with hybrid structure between typical tropical hurricanes and extra-tropical systems" (Silva Dias et. al., 2004). In any case, the event was seen as a warning about the possibility of climate change materialising under exceptionally favourable conditions for the transformation of the emergency patterns of extreme hydrometeorological phenomena (Pezza \& Simmonds, 2005).

In October 2015, predictive models again failed - but in a more dramatic way. The storm Patricia hit the west coast of Mexico and the initial forecast was that it would be another typical low category hurricane in the Pacific. However, Patricia changed her trajectory and intensified at an unprecedented speed, becoming, in approximately 24 hours, the most powerful hurricane ever recorded in terms of maximum sustained wind velocity $(325 \mathrm{~km} / \mathrm{h})$, breaking several global records in the western hemisphere (Rogers et. al., 2017; Nystrom \& Zhang, 2019). Following a completely contingent 
behavior, while still over the sea hurricane Patricia surprisingly weakened, also very quickly, thus reaching a only a scant rural land area in the state of Jalisco, Mexico, leaving seven dead and approximately 325 million dollars in damage (Kimberlain et. al., 2015). In comparison, the damage caused by hurricane Katrina (2005) is estimated at more than 100 billion dollars, with about 1,500 deaths directly caused by the phenomenon (Beven et. al., 2005). In the end, the behaviour of hurricane Patricia followed a trajectory of unpredictability as set by the models used to predict phenomena of this nature and by the official channels; being at first greatly underestimated, and then later overestimated for its potential damage.

Extreme hydrometeorological phenomena such as these induce at the individual and global level several speculations related to the possibility of a world without us. In the wake of these speculations and the imaginary linked to climate change, more precisely related to the incidence of storms, there is the case of skulls seen in infrared images of hurricanes made by satellites that frighten internet users on social networks, as in the cases of Hurricane Matthew (2016) and Michael (2018) (see Zenteno, 2016; Phillips, 2018).

However, the climate crisis materialises in many other ways besides the incidence of cyclones, hurricanes or typhoons. Events such as extreme droughts, floods, and other phenomena impact a number of processes at the local and planetary level, including the lives of microorganisms that may or may not be pathogenic. Insects and other animals are also impacted, constituting vectors or intermediate hosts of microorganisms harmful to human health, dramatically diversifying the distribution and transmission of diseases in the tropics. Currently, there is strong evidence pointing to the incidence of extreme weather events and changes in rainfall and temperature patterns, among other factors associated with climate change, playing an important role in the emergence and re-emergence of multiple neglected tropical diseases (such as dengue, chikungunya and leishmaniasis), including their transmission periods and expansion to areas never before affected (Tidman et al., 2021). In addition, permafrost thawing in the Arctic region has been releasing fungi and bacteria dormant for thousands of years, also constituting a risk to human health (Revich \& Podolnaya, 2011; Lagendre et al., 2015). In a related sense (and with a sense of prescience), the Brazilian animated short film Entrevista com o Morcego (Interview with the Bat), launched back in 2000 by Dustan Oeven and Moisés Cabral, depicts, from the animal's perspective, how the destruction of bat habitats by floods, for example, bring these animals closer to urban centres, intensifying the spread of diseases. Similarly, the entanglement between the dramatic persistence of the COVID-19 pandemic and the rising ocean level in the speculative fiction "Goodbye on the Seas" (see Yin, 2021, this issue) is pertinent in remembering that very distinct events can originate in climate and 
terrestrial changes of anthropogenic background, with possibilities for tragic futures in their joint performance.

Thus, human action, conscious or not, induces unexpected effects that feed an imaginary that suggests the future as a catastrophe. Fiction and reality go hand in hand because we are not able to delineate a tangible boundary between them, even as we are engaged in constantly chasing phenomena that manifest themselves in total indifference to human reason. The IPCC itself is aware of the problem of 'uncertainties' and 'deep uncertainties' that permeate scientific studies and the communication of their results, since climate change is felt in different ways in various regions of the planet, while various social variables (such as political positions and ethical values) also interfere in the way different groups react to the very possibility of climate change (Chen et al., 2021, pp. 29-32). For this reason, analysing how climate changes, and their signs, emerge in the imaginary of the tropics is fundamental for generating responses to the unprecedented phenomena that humanity is experiencing in the $21 \mathrm{st}$ century.

\section{Articulate Imaginings}

The articulation of various tropical imaginaries as they emerge through climate crises, is the work of the twelve papers brought together in this Special Issue. Here, the authors articulate nuances of climate change related events as they effect specific tropical countries and regions. In addition to addressing tropical imagination and many inter-related aspects of climate crises, the papers have in common a concern with how various forms and eras of mercantile colonialism and capitalist neo-colonialism have impacted the tropics. Individually and collectively the papers stress how a new imaginary requires local voices, including voices from the many diverse cultures of the tropics - indigenous as well as cultures formed as legacies of slave trade, indentured labour and migration.

There are many resonances between these papers - which we invite readers to explore for themselves - and here we offer merely one of many ways in which to read them for their thematic reverberations. We do this by grouping them under subheadings. Thus we bring together several essays under the theme of Decolonising Climate Change, two articles under Material Culture \& Vernacular Knowledge, a variety of forms of literary analysis under the heading Ecocriticism \& Postcolonialism, and end with speculative fiction pieces under the theme Tropical Apocalyptic.

In these papers we encounter tropical imaginaries as they arise in varied articulations: storied existences of both human and beyond-human communities; of minifauna parsed through DNA barcoding; of rhizomatic identities formed and morphed in 
mangroves through photography; the architectural heritage of a climate ravaged Basilica; revival of vernacular knowledge for natural and climate disaster resilience; the entwined relation of fossil fuels, capitalism and climate change; the reimagining of hurricane tropes in contemporary comics, and in another paper, storm tropes in early postcolonial writing of the fin de siècle; the material poetics of a long El Niño drought; ecocide in novels set during civil war; climate fiction of nuclear testing and biohacking set in the far climatic future looking back; and a hybrid fiction combining real life and dystopian speculative futures in rising seas.

\section{Decolonising Climate Change}

The first three papers are all involved in decolonising climate change by setting the current climate crisis within legacies of the colonialism. Each proposes the need for local voices and different forms of climate storying. The papers bring us to Papua and Samoa in the Pacific Ocean, to the Indian Ocean Island of Madagascar off the coast of Africa, and to the 'Black Pacific' coast of Ecuador in Latin America.

\section{Beyond-Human Imaginaries - Papua and Samoa}

Drawing on personal and academic knowledge from West Papua to Samoa, Sophie Chao and Dion Enari call for transdisciplinary, experimental and decolonial imaginings of climate change for the future of the Pacific. In their paper, 'Decolonising Climate Change: A Call for Beyond-Human Imaginaries and Knowledge Generation' (2021, this issue), the two scholars set out practices and principles that call for a rethinking of our relation with the more-than-human world. In their view, it is not the imagination that is at issue but the small and "exclusionary scope of voices and beings heeded and represented by current dominant climate imaginaries" (Chao \& Enari, 2021, this issue, p. 34). Such imaginaries perpetuate visions of human mastery over a passive nature that remains merely an inert resource for the machinations of humans. They argue that the climate and environment itself can serve to ignite and unite our imaginings through animate cosmologies and philosophies. This reframed relational imagination can begin through including voices of Indigenous peoples of the tropics and beyond who have always recognised the interdependencies of human with otherthan-human beings and, further, the elemental forces. They also argue that in academic storying it is imperative to decolonise our texts and note that a reflexive and relational ethnographic and theoretical practice offers one way to move beyond Western theoretical domination and take seriously Indigenous peoples' theories and philosophies of climate and environmental crisis. As the authors state: "The climate crisis is a multi-faceted problem, therefore it demands transdisciplinary responses" (2021, p. 42). 
Importantly, Chao and Enari offer stories as hope. "In repeating the names and stories of organisms pushed to the edge of extinction, we refuse to forget their liveliness, symbiotic existence, and consequential presence....Drawing into stories our peoples, oceans, forests, mountains, animals, and ancestors, we fa'aola (bring to life) the urgency of the climate crisis and the responses it demands of us (2021, p. 38)

\section{Cryptic and Miniature Species - Madagascar}

Recent photographs and reports of "new" miniature species has captured the public imagination. However, as Genese Sodikoff, in her article 'Shrunken Life: Discourses of the Cryptic and the Miniature in Madagascar' (2021, this issue) reminds us, this discovery of minifauna evolves out of habitat loss as a result of environmental degradation and the impacts of climate change. The species discoveries come as scientist scour remnants of forests or they are revealed through DNA barcoding which is capable of detecting nuanced differences in species.

In Madagascar, discoveries of miniature frog and chameleons are photographed on the tips of human fingers, while a mini lemur is cradled in a hand. In a finely rendered analysis, Sodikoff notes that this imagery of scale evokes how the giant finger or cupped hand can be read as the outsized impact of humans on the planet. She states that: "the quest to find novel species in a context of mass extinction and global warming resembles the impulse of White museum curators of the nineteenth century" (2021, this issue, p.56). To understand why the 'new' minifauna are so fascinating, Sodikoff takes up Susan Stewart's evocative work, On Longing: Narratives of the Miniature, the Gigantic, the Souvenir, the Collection (1996), and uses its insights to follow early imaginaries of dwarfism and giantism in European scientific, anthropological and literary texts - with their theories of evolution and extinction - as well as local Malagasy mythologies.

Sodikoff, never loses sight of how the wonder of these tiny species must be read against the backdrop of mass climate extinctions, which will be more pronounced in the tropics where rainforests and other tropical ecologies have supported rich species biodiversity.

\section{People of the Mangrove - Ecuador}

Yairen Jerez Columbié's paper, 'People of the Mangrove: A Lens into socioecological interactions in the Ecuadorial Black Pacific' (2021, this issue) explores the interrelations between mangroves, children, legacies of colonial slavery, the struggle for livelihoods, and mangroves as places of play. The piece shows the relation between people and the plants they live among and the ecosystem on which their lives depend. 
Set in the Ecological Mangrove Reserve Cayapas-Mataje in Ecuador, this ethnographic study of the Afro-Ecuadorians who live in the mangroves is articulated through photographer Felipe Jácome's photographic essay Los Reyes del Manglar [The Kings of the Mangrove]. Jerez Columbie furthers the rhizome imagery of the mangrove forest through Caribbean thinker Édouard Glissant's work on rhizomatics in order to think though a "Poetics of Relation, in which each and every identity is extended through a relationship with the Other" (Glissant, 1997, quoted in Jerez Columbié, 2021, this issue, p. 78). She notes that mangroves are rich material for the study of the history of these forests and the entanglements with people's lives, cultures, and histories.

Mangroves survive in the interstice between land and sea and are vulnerable to the impacts of climate change, they also play an important role in carbon sequestration and climate change mitigation. Jerez Columbié argues that cultural representations of mangroves can go beyond their metaphorical meaning, for they are socioecological systems that support people's struggle for climate justice.

\section{Material Culture \& Vernacular Knowledge}

The two papers that follow are set in different parts of Monsoonal Asia. One article addresses material culture and argues for vernacular knowledge in architectural heritage conservation in Goa, South Asia. The other article argues for the need for vernacular knowledge in the materiality of natural and climate disaster resilience and management with case studies from Japan, Thailand, and Indonesia.

\section{Rain in the Basilica - Goa}

In many parts of the tropics monsoon deluges are becoming more intense due to climate change, including Goa. Vishvesh Prabhakar Kandolkar's study, 'Rain in the Basilica: Protecting Goa's Bom Jesus from the Ravages of Climate Change' (2021, this issue) explores the effects of monsoonal climate change on the architectural heritage of this small coastal state which was once under Portuguese colonial rule, but during postcolonial manoeuvres was annexed to India. The Basilica of Bom Jesus, is one of the most important cultural icons of Goa and a symbol Indo-Portuguese heritage. It also holds the relics of St. Francis Xavier and is thus an important pilgrimage site. The sixteenth-century building is still in use, despite its roof having been breached by rains, and its laterite stone exterior walls being eroded by the lashing of monsoon deluges. As he takes us into the controversies surrounding the conservation of the Basilica, Kandolkar argues that in these pressing times of climate change, architectural conservation cannot be about just the preservation of cosmetic 
appearances of buildings, but must involve safeguarding monuments against major structural damage. The article explores the cultural, historical, colonial, political, architectural, and tropical monsoonal factors affecting the Basilica's current deterioration and its future conservation. Kandolkar notes: "Because monuments like Bom Jesus do not stand independently of their environments, the imagery of climate change is incomplete without considering its effect on architecture" (p. 98).

As this issue goes to press, Kandolkar's work on material culture and monsoon is extending its reach through his photographs which are opening in the group exhibition entitled 'Goa: A Time that Was' (D' Souza, 2021). Kandolkar advises that he has hung woven palm fronds, called mollam, in front of a large photograph of the Basilica in reference to indigenous practices on vernacular architecture - which was inspired by his article for this Special Issue (see p. 106). (Kandolkar, per com, 6.9.2021).

\section{Vernacular Knowledge and Natural Disaster-Monsoon Asia}

In his article 'Vernacular Knowledge, Natural Disasters, and Climate Change in Monsoon Asia' (2021, this issue), Senjo Nakai discusses how climate change impacts the ability to predict and prepare for natural disasters, thus increasing the risks of climate related hazards. In the modern past, science and technology were instrumental in the management of natural disasters. However, with the contingencies of climate change, predictive measures are proving less reliable as Monsoon Asia experiences extreme weather events.

In the more distant past, the peoples of Monsoon Asia had for centuries prepared themselves for natural disasters through a repertoire of mythologies, collective memories, artefacts, songs, sayings, artworks, and customs. As Nakai argues: "Such knowledge, while not readily compatible with scientific discourse, is by no means at odds with it. With ingenuity, vernacular knowledge can be a valuable medium for people to understand and cope with such multifaceted phenomena as climate change" (p. 116). Indeed, his article offers examples of how such local knowledge has been utilised successfully by peoples of Japan, Thailand, and Indonesia in local disaster management.

Nakai's article offers us an in-depth examination of the concept of Monsoon Asia and discusses the relation between climate change and natural disasters, he also provides the reader with inspiring examples of vernacular knowledge of disasters and their articulation through tangible and intangible heritage. 


\section{Ecocriticism \& Postcolonialism}

This subtheme brings into relation papers employing literary analyses. The first paper, written from a global studies perspective, is a critique of colonialism, extractive industries and imperialism. It argues for the joining of ecocriticism and postcolonialism and draws on examples from the tropics. The following papers put into practice this ecocritical-postcolonialism through finely articulated pieces that arise from local climate change conditions in various tropical locations, including: hurricanes in Puerto Rico analysed through comics; journeys of weather and storm tropes in the fin de siècle writings of José Rizal in the Philippines; a deep musing on the phenomenology of time during an El Niño drought in the Philippines through poetry and farmers' protests; and an exploration of ecocide, eco-anxiety and climate change in two novels by Aminatta Forna set in war-torn Sierra Leone, Africa.

\section{Climate Imperialism - the Global Tropics}

Rachel Hartnett, in her paper, 'Climate Imperialism: Ecocriticism, Postcolonialism and Global Climate Change' (2021, this issue), writes from a global perspective which is punctuated and elucidated through numerous examples from tropical regions. Arguing for a joining of ecocriticism and postcolonialism she sets out the background of each field and the work that has recently been undertaken by theorists to bring them into relation. The paper utilizes, with close attention to quotations, the works of leading academics in each of these fields. Her critique is especially rigorous of America and the Global North, from where the author hails; while the many climate change examples cited throughout the article are in themselves a testament to the climate emergency unfurling in the tropics.

Hartnett argues that "Global climate change reinforces disparate economic, social, and racial conditions" - following the paths that were laid out during colonialism. This, she elaborates, inscribes "climate change as a new, slow form of imperialism" (p. 139). She further argues that the negative impacts of climate change "will be distributed not just unequally, but in a direct echoing of colonial pathways" ( $p .140)$. She reasons that climate imperialism can only be ruptured though a postcolonial focus and indigenous resistance.

The paper concludes by demonstrating how an ecocritical-postcolonial relation is arising through critical and creative works of peoples from countries of the tropics. She notes: "That these scholars and writers are rising up from tropical nations that have faced the longest and most intense colonialism is not a coincidence" ( $p .152)$. 


\section{Gifts of the Hurricane - Puerto Rico}

This paper introduces comics as a source of decolonial imaginary based in experiences of hurricanes. Daniel Arbino's '"The Gifts of the Hurricane:" Reimagining Post-María Puerto Rico through Comics' (2021, this issue), acknowledges the tragedies following hurricanes Irma and María in Puerto Rico, but also brings to our awareness a series of comics that have emerged to form a small literary canon that "explores the storms as an opportunity to rethink the island's future" (p. 157).

He notes that the hurricanes forced artists and writers to engage with both climate impacts of rising seas and intense tropical storms, and with re-evaluating the colonial relationship of Puerto Rico with the USA. Arbino argues that these seemingly disparate elements became connected through the United States' mishandling of the ensuing recovery which prompted a responding outpour of decolonial imaginaries, which he defines as "a rupturing space, the alternative to that which is between the colonial and postcolonial, that interstitial space where differential politics and social dilemmas are negotiated" (Pérez, 1999, quoted in Arbino, 2021, this issue, p. 157). Arbino notes that the notion of this interstitial space is particularly pertinent to the situation of Puerto Rico where cultural production must manoeuvre the in-between spaces of being Caribbean, American and Latin American simultaneously.

Guiding the reader through selections of texts from both English and Spanish comics, Arbino shows us how the comics, through Hurricane María, create an autonomous island future. Collectively, these comics offer both a return to pre-colonial indigenous values, and an imagining of new technologies "to empower Puerto Rico to break from the United States and withstand future storms" (p. 157).

\section{Atmosfera Rizaliana - the Philippines}

Storm tropes emanate throughout Isa Lacuna's paper 'Atmosfera Rizaliana: Metonymic Journeys of Weather in José Rizal's Philippines' (2021, this issue). As she notes, stormy weather is a recurring theme in the literary and political oeuvre of José Rizal, one of the Philippines' most celebrated figures - as both writer and political martyr.

Through Rizal's stormy tropes, Lacuna undertakes a theoretical and material excursion into exploring the metonymic logic that threads not only through the writerpolitical activist's texts, but also other movements of the fin de siècle across cultural, technological, and political landscapes between the metropole in Spain the Philippine archipelago. Lacuna writes of the weather in fragments as the circulation of ideas and 
discourses, travelling along cultural circuits of books and films, but also as technologies - ice shipped in tons to the archipelago (the temperate reaching the tropics). As she states: "It is instructive to view turbulent weather, both in the historical and contemporary case, as not simply a natural phenomenon that happens, but as a catastrophic intersection of technological, historical, and political factors whose experiences are never divorced from one another" (p. 202).

Just as Rizal deployed weather as part of a political and anticolonial rhetoric of solidarity across space, Lacuna suggests that the climate crisis may be informed by the logic of metonym deploying "horizontal relations between peoples and their surrounds, asserting the significance of lateral disruptions to metaphoric hierarchies." And moving further into "larger horizons that span the full scope of the planetary" ( $p$. 203).

\section{Time and an El Niño drought - the Philippines}

The imagery of a long drought frames Christian Jil Benitez's paper 'On the Weariness of Time: El Niño in the Philippines' (2021, this issue). Here, in the form of a 'tropical imaginary' and a 'material poetics' Benitez accentuates the entanglement of literature (through poetry) with the material world (through farmers' protests). He 'coincides' the 1965 poem 'The Weariness of Time' by Jose F. Lacaba, with the 2015 El Niño drought in the Philippines which culminated in a violent clash between police and farmerprotesters in Kidapawan City, Mindanao.

Benitez's text is framed by poetry at the beginning and end, thus moving the reader in and out of poetic reverie, literary analysis, specifics of weather, and political critique. He moves us between the farmer of the poem and the farmers of the El Niño event. Yet the two also 'coincide' and begin to seep one into the other. Benitez writes: "as the river runs dry and the earth becomes barren, the farmer still possibly dares to imagine the prospects of adapting, if not outright flourishing, amid the present crisis albeit in ways that may differ from what they were formerly accustomed to" (p. 212).

As the author muses, 'the weariness of time', is also manifest in the continuing applicability of Lacaba's poem across a period of 50 years to the El Niño event, for it indicates that in some ways time has not changed, and farmers "are still ultimately deprived of sufficient relief and structural support from the government, and instead coerced to perceive that their suffering will always be "how it really is," leaving them to their own devices" (p.216). 


\section{Climate Change and Ecocide - Sierra Leone}

Shruti Das and Deepshikha Routray in their paper, 'Climate Change and Ecocide in Sierra Leone: Representations in Aminatta Forna's Ancestor Stones and The Memory of Love' (2021, this issue), analyse how Forna's two novels direct the reader to the issue of climate change due to the severe impact of mining and deforestation in Sierra Leone. While both activities began with colonialism, they were especially intense during the nations postcolonial period which instigated a series of civil wars which continued for over eleven years from 1991 to 2002 and wrought havoc on both land and forests. The authors are particularly interested in how the trauma of ecocide is represented within the two novels, including through personal trauma depicted through various characters.

In order to analyse trauma of the characters, the paper draws on scientific and sociological data and places it within the context of narrative episodes in the novels. The anxiety and post-traumatic stress disorder - of both war and ecocide - suffered by the fictional Sierra Leonean characters are explained through Cathy Caruth's trauma theory, "which sheds light on the metaphorical representation of inexpressible trauma" (p.230).

War as an instrument in the destruction of land and forests is a major contributor to climate change. Mining is carried out for minerals to fund wars, and deforestation is caused by felling of trees as well as setting areas on fire in order to destroy forest cover, thus preventing people from hiding. Das and Routray point out that the anxiety and trauma suffered by people exposed to war, not only includes the more visible aspects of human ethnocide, but also the long lasting effects of ecocide. Their paper demonstrates how narratives can metaphorically represent both ecocide and climate change and their revelation can help people to face stress in the physical world.

\section{Tropical Apocalyptic}

The two final papers are speculative fiction pieces set within watery realms. One paper is a climate fiction piece that takes us to Enewetak Atoll in the isolated tropical Pacific Ocean and the far future. The other paper, which combines memoir and speculative fiction, begins in the contemporary era - with a projection into a future of forever morphing pandemic and rising seas surrounding Malaysia and the island of Borneo.

\section{Post-Quantal Garden - Enewetak Atoll}

Enewetak Atoll comprises forty low-lying islands surrounding a deep central lagoon. During the cold war, along with other atolls in the Marshall Island group of the Pacific, 
it was a major site of nuclear testing. In Jake Boswell's, The "Post-Quantal Garden" Annotated (2021, this issue), we enter the realm of climate fiction (cli-fi) set in the future and looking back on a post-apocalyptic planet. Boswell opens his story with these words: "Of the many tragedies that befell the world in the wake of climate change, the loss of the Marshall Islands was a minor but important early augur of the devastations that would mark the latter half of the $21^{\text {st }}$ century." He continues by noting that the small group of coral atolls, which rest only a few metres above sea level: "were among the first places in the world to disappear beneath the rising waters of the diluvial period" (p. 241).

'The Post-Quantal Garden' is a fusion of fact and fiction incorporated into a rumination on nuclear testing, on bio-hacking, and climate crisis. It brings J.G. Ballard's 1964 short story "The Terminal Beach", and that author's fascination with tropicality and the apocalyptic, into relation with the techno-political history of nuclear bomb tests and radiological clean-up - during which the diary of the "Post-Quantal Garden" was (fictionally) discovered. The author provides a detailed map of the atoll and test sites.

The piece also holds hope in the form of the discovery of a new species of giant kelp, Macrocystis enewetaciae (named after the atoll), the 'seasteading' movement, and carbon farming and sequestration. Boswell reminds us: "If there is a single point on Earth where the entangled origin of the Chthulucene can be located, it may very well be the sublime blue of Enewetak's submerged lagoon" (p. 241-242).

\section{Rising Waters, Submerging Lives - Malaysia and Borneo}

In the last paper in this collection, Christina Yin, in "Goodbye on the Seas: Rising Waters, Submerging Lives" (2021, this issue), makes us reflect on our current years of pandemic and climate crisis, and projects us into the future. Her hybrid memoirspeculative fiction begins and ends with the sea. Starting with real-life story, the author brings us to the Straits of Malacca off the coast of Peninsular Malaysia where her father's ashes are spread into the waters. The second part of the story takes us to 2050. Here we meet the author again, older and worn down by the double crises of pandemic and climate. Here in the future, we find that the pandemic has never ceased as the coronavirus continues to morph, while global warming and the melted polar icesheets have caused the rising seas to engulf cities of her native tropical island of Borneo in Malaysia.

The ending comes in the form of the daughter telling the spirit of her deceased father a fictional story of setting out into the engulfing waters. In the author's final words: 
When the sun has peaked overhead and it is the hottest part of the day, I take off my jeans and t-shirt, stripping to my swimsuit. Then I step into the water. The waves are gentle and the water is warm, just like how I remember. When the water is waist high, I push off with my toes from the sandy sea bed.... With long smooth strokes, I reach out to the horizon where the sea never meets the sky. I am swimming in the South China Sea which is slowly rising in a world that will never be the same. It's not a world I belong in, so I will find my way in the rising seas. (p. 262)

\section{Finalé: Entwined Futures}

The double crisis of pandemic and climate also acts to remind us of the threats of emergence diseases as the world warms and the tropical zone expands outwards further into temperate latitudes. This expanding tropics, as a manifestation of climate change, also requires expanding tropical imaginaries. How can we move away from global discourses of Norths and Souths as climate change ruptures - through heat waves and tropical storm bursts - what has always been imagined as the temperatelyrestrained latitudes?

At the same time we need a Tropical Imaginary to address how climate change is also changing the tropics itself, climatically, culturally, through neo-colonial practices - and how the current crisis rests with the history of mercantile colonialism. Furthermore, we need to think through and with climate, weather systems, archipelagos, animals and plants; and listen to the voices and cosmological worldviews of Indigenous peoples and those descended from slaves and indentured labourers.

We also need philosophic/interdisciplinary imaginaries that can offer relational ways of thinking and being - of bringing different disciplinary ideas together while going beyond the disciplined thinking of academic disciplines. And here we are reminded of the anthropologist Gregory Bateson's koan: "What is the pattern that connects the crab to the lobster and the orchid to the primrose, and all four of them to me? And me to you?" (1979, p. 8). In today's climate crisis scenario we could appropriate Bateson's koan to ask: What is the pattern that connects carbon dioxide, frequencies and intensities of terrestrial and marine heatwaves, of monsoon deluges and droughts, of wildfires and intense tropical storms, of melting Polar ice sheets and mountain glaciers, of rising seas, river floods, and waves surges, and all of them to me? And me to all of them? 
Bateson's relational thinking wove:

anthropology, early network theory, and images into an interdisciplinary practice that was inspired by his ethnographic fieldwork in Bali which ranged across art, dance, trance, drama and music, and his reading of Alfred Russel Wallace's The Malay Archipelago (1890 [1869]) where the co-theorist of evolution observes the interdependence of natural systems. (Lundberg et al. 2019, p. 2).

And we note that the very notion of evolution (and its rupture with divine creation) itself arose out of the tropics; simultaneously from two tropical regions, and two theorists. Thus, while Charles Darwin was in the Galapagos Islands in the Ecuadorial Pacific, Alfred Russel Wallace was on the other side of the Ocean in the Indo-Malay Archipelago. Yet Wallace's work has been taken up in quite a different way to Darwin's. While Darwin's notion of evolution has been incorporated into social Darwinian evolutionary hierarchies (tree images), Wallace has been taken up to demonstrate early ideas of ecology (rhizomatic thought). Bringing into relation nascent ideas of ecology and cybernetics through a deep questioning of patterns of thought, Bateson's 'ecology of mind' project helped inspire the contemporary philosophy of rhizomatics.

Rhizomatics conjures up tropicality. It was introduced by the French philosopher Gilles Deleuze and psychotherapist Félix Guattari (1980/1987) as an image of thought based on the rhizome plant - gingers, galangal, turmeric, lotus root, bamboo, sympodial orchids.

The root system of rhizomes forms horizontal networks in which nodes of the root may spread out in any direction. In turn, nodes hold the potential to multiply, creating ever growing networks. If cut from its root network and replanted, a node will continue to grow - forming a new root network and sprouting forth a plant. This pattern of growth is emblematic of rhizomatic theory, for there is no origin or hierarchy in the rhizome: every node holds the potential to connect and expand, to start anew (Deleuze \& Guattari, 1987; Lundberg, 2013). In Deleuze and Guattari's work, the horizontal and pliable network image of rhizomes is juxtaposed to the rigid hierarchical image of the tree with its deep penetrating roots, upright trunk and radial branches - the arboreal image upon which traditional Western philosophy bases notions of evolution, development, progress, and knowledge; the same ideals that strongly underpinned colonialism. (Lundberg, et al. 2019, p. 2) 
This is not to suggest that rhizomatic thought is anti-tree. "The tropical banyan tree, with its spreading branches that drop down tendrils to the ground, which sprout roots to form new trunks that then branch out to create an expansive network of a tree, is an especially poignant rhizomatic image" (Lundberg, 2019 pp.2-3; 2008), as are those interstitial rhizomatic plants of the world's tropical mangroves. Rhizomatics, in short, is non-linear, it invites us to perceive the intertwinings that are the workings of the world.

Rhizomatics, inspired by mangrove imaginary, was further taken up by Martinican theorist and writer Édouard Glissant as a way of thinking his Poetics of Relations (1990/1997). As the book's translator Betty Wong summarises, "Glissant sees imagination as the force that can change mentalities; relation as the process of this change; and poetics as a transformative mode of history" (Wing in Glissant,1997, p.xii). Interstitial mangroves further inspired Glissant's archipelago consciousness which explores the interrelations of exchange throughout the Caribbean involving plants, peoples, places, languages, cultures (Jerez Columbie, 2021, this issue, pp. 78-79). Although archipelagos are commonly dominated by a vision of islands, we need an archipelago imaginary which allows us to perceive spaces and relations of elements: oceans and atmospheres, El Niño and La Niña events, and weather spiralling tropical storms (see Arbino, 2021, this issue), and the debilitating stillness of droughts (see Benitez, 2021, this issue). Furthermore we need a tropical archipelago imaginary to understand how far reaching climatic phenomenon are intricately entwined with local-region manifestations (Lundberg, 2021, p. 93 ).

The future necessitates imaginaries capable of seeing these complex intertwinings of climate, geography, animals, plants, weather - these more-than-human worlds as they are entwined with our human material worlds with their histories of colonialism, slavery and migrations, plants and animals, plantations and extractivist mining, capitalism and oil-based industries, and neo-colonialism. To humanise climate change is not to remove it from nature systems, but to imaginatively understand how the human is intricately bound with, and intimately implicated in, the climate crisis.

We and the planet, together, are at a crucible. We are under a severe test, we need new ways of thinking, and a rupture with old ways. Indeed, as we near the COP26 UNFCCC Climate Change conference to be held in Scotland in November, there has been a worldwide rise in calls for a radical reduction in greenhouse gases, especially $\mathrm{CO}_{2}$. The call comes in the form of academic articles, activism, film documentaries and literary writings.

In a special issue of the Scottish Geographical Journal the theme "Climate Change, COP26 and the Crucible of Crisis" (Warren \& Clayton, 2020) brought together papers 
from many countries on science, social science, art, humanities and climate activism, including a statement from Grandparents For Future (a branch of the Fridays For Future school activists located in Sweden) that acknowledges young people's ecoanxieties over climate change and speaks in support of the school students' strike which, in times of global pandemic, continues through social media (Ardelius, et al., 2021).

In Australia - where recent climate change manifestations have included prolonged drought, extreme wildfires and floods - students have also been striking. The feature documentary Wild Things: A Year on the Frontline of Environmental Activism (Ingleton, 2020), maps the protests of this new generation of environmental and climate activists. Inspired by Greta Thunberg's Friday strikes, young eco warriors, armed only with their mobile phones, are protesting to save their futures. They employ the non-violent tactics of the grandparents, sitting high in the canopy of rainforest trees, chaining themselves to coal trains, blocking bulldozers - and sending their messages out to the world through social media. The documentary incorporates video phone footage from protesters, intermixed with footage of earlier campaigns in Australia, showing a legacy of environmental awareness and the offer of hope for today's climate action.

In Bali, this year's theme for the Ubud Writers and Readers Festival (UWRF) is 'Mulat Sarira: Self-reflection'. In Balinese-Hindu philosophy this is a deep spiritual principle of reflecting on one's thoughts, values and actions. This act of introspection necessitates that we slow down, pause. And it thus invites syncope, which is fundamental to the emergence of different ways of being and knowing. Catherine Clément speaks of syncope in her philosophy of lack as the missing beat: "It is essential for the beat to change register, and it is syncope, either visible or hidden, that does the work. From that moment something stops, life perhaps, or habit, the daily routine...." (Clément 1994, quoted in Lundberg, 2001, p.540). And it is this rupture that enables movement. Through this gap "the possibilities for new relations and ways of being may arise" (Lundberg, 2001, p. 542). Here in self-reflection we are invited to lose our sense of self in order to experience the intricate relations with the world around us - from which we are never removed.

As part of the lead up to the event in October, the Ubud Writers and Readers Festival has been sharing writer's self-reflections, including a quote from Amitav Ghosh's book The Great Derangement: Climate Change and the Unthinkable (2016). But it is to the writer's latest book that we now turn, a book that he will speak about at the Festival. The Nutmeg's Curse: Parables for a Planet in Crisis (2021) maps the origins of the climate crisis in colonialism's exploitation of humans and the environment. Ghosh traces the nutmeg back through the history of mercantile colonialism and the seas of the Spice Islands to the Banda group in Maluku (the Maluccas). Nutmeg is endemic 
to this one small cluster of volcanic islands in the far eastern Indonesia archipelago. Through this aromatic spice arises stories of the discovery of the New World, of sea journeys, violent conquests, the exploitation of humans and environments, and a Western imaginary that saw tropical peoples and nature as mere resources - the same imaginary which continues into current practices of neo-colonialism.

Yet, in Ghosh's storying these are not distant or far away events; rather, we are brought close to the nutmeg, to the planet as a vital force, to mythologies and cosmologies. The Nutmeg's Curse offers a tropical imaginary as it maps the historical and geopolitical origins of the current climate crisis.

Figure 1. Mulat Sarira: Self-reflection

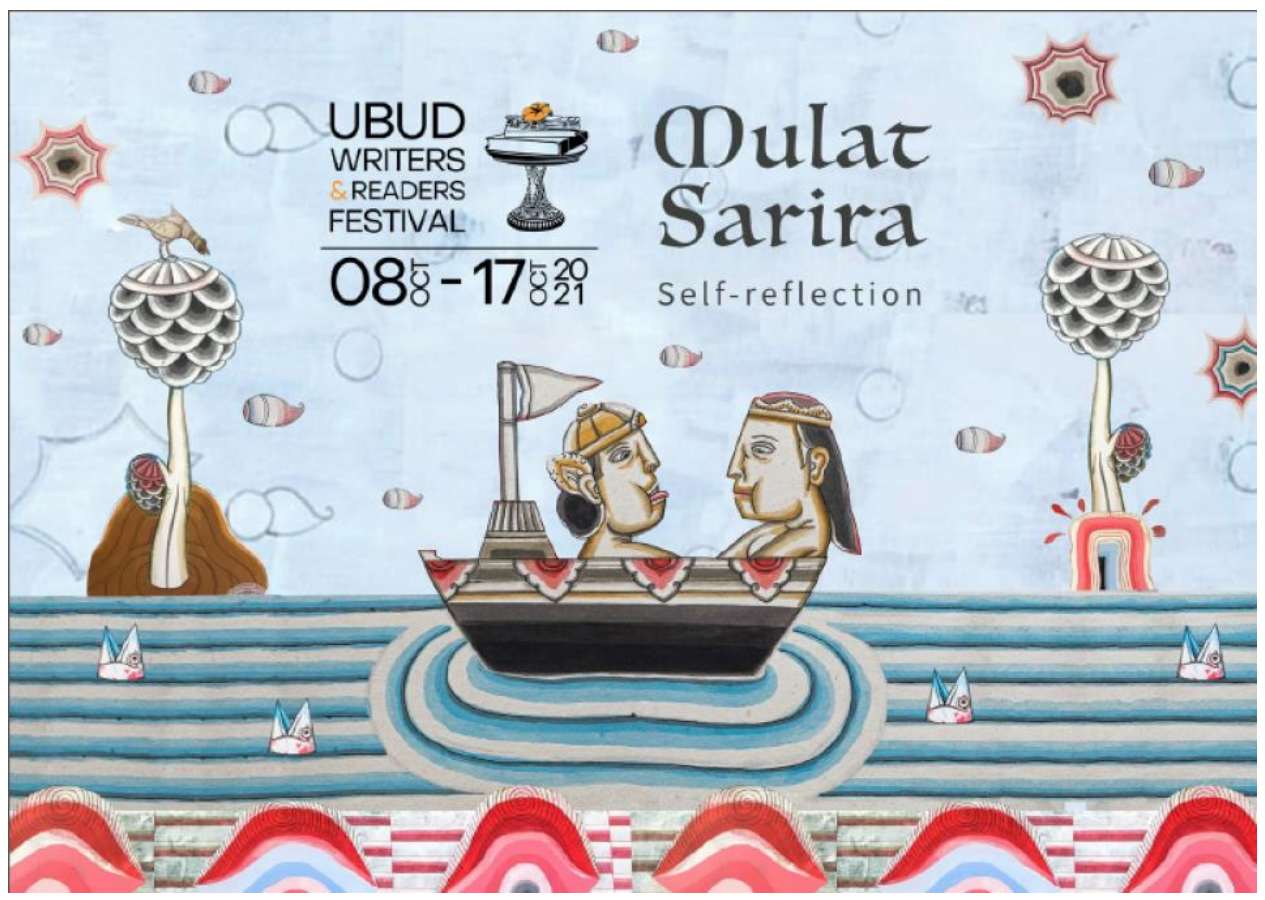

Artist: Teja Astawa, in Kamasan style, Bali. https://www.ubudwritersfestival.com/

Teja Astawa's artwork evokes his reflection on Mulat Sarira: "I used traditional elements to mirror ourselves" (quoted in UWRF, 2021). Kamasan is a traditional Balinese narrative style of painting. The depictions of various landscapes, characters, animals, plants, and elements, tell stories. The story we read in Teja Astawa's painting is one of seas and island archipelagos, of trees (is that a nutmeg tree?) and birds, of suns and stars, of clouds and winds, of waves and fish, of boats and the movements of peoples across vast seas, and of traditions of storytelling. 


\section{References}

Arbino, D. (2021). "The Gifts of the Hurricane:" Reimagining Post-María Puerto Rico through Comics. eTropic: electronic journal of atudies in the Tropics, 20(2), 156- 179. https://doi.org/10.25120/etropic.20.2.2021.3815

Ardelius, A., Bylund, S-T, Güettler, K., Hammarbäck, L., Keith-Rosander, Nilsson, E.M., Ramirez de Bylund, A., Sundbaum, B. \& Söderbäck Güettler, G. (2020) We, grandparents, object to passing a wrecked climate to coming generations! The Scottish Geographical Journal, 136 (1-4), 72-74. https://doi.org/10.1080/14702541.2020.1863606

Bateson, G. (1972). Steps to an Ecology of Mind: Collected Essays in Anthropology, Psychiatry, Evolution, and Epistemology. University of Chicago Press.

Bateson, G. (1979). Mind and Nature: A Necessary Unity. (Advances in Systems Theory, Complexity, and the Human Sciences). E. P. Dutton.

Benitez, C. J. (2021, this issue). On the Weariness of Time: El Niño in the Philippines. eTropic: electronic journal of studies in the Tropics, 20(2), 209-220. https://doi.org/10.25120/etropic.20.2.2021.3819

Beven, J.L. II, Avila, L.A., Blake, E.S., Brown, D.P., Franklin, J.L., Knabb, R.D., Pasch, R.J., Rhome, J.R., \& Stewart, S. R. (2008). Annual Summary: Atlantic Hurricane Season of 2005. Monthly Weather Review, 136 (3). 1109-1173. http://www.aoml.noaa.gov/general/lib/lib1/nhclib/mwreviews/2005.pdf.

Boswell, J. (2021, this issue). The "Post-Quantal Garden" Annotated. eTropic: electronic journal of studies in the Tropics, 20(2), 240-250. https://doi.org/10.25120/etropic.20.2.2021.3817

Chakrabarty, D. (2009). The Climate of History: Four Theses. Critical Inquiry, 35 (2) (Winter), 197-222. https://doi.org/10.1086/596640

Chao, S., \& Enari, D. (2021, this issue). Decolonising Climate Change: A Call for BeyondHuman Imaginaries and Knowledge Generation. eTropic: electronic journal of studies in the Tropics, 20(2), 32-54. https://doi.org/10.25120/etropic.20.2.2021.3796

Chen, D., Rojas, M., Samset, B.H., Cobb, K., Diongue, A., Niang, A., Edwards, P., Emori, S., Faria, S.H., Hawkins, E., Hope, P., Huybrechts, P., Meinshausen, M., Mustafa, S.K., Plattner, G. K., Tréguier, A.M. (2021, In Press), Framing, Context, and Methods. In: Climate Change 2021: The Physical Science Basis. Contribution of Working Group I to the Sixth Assessment Report of the Intergovernmental Panel on Climate Change [Masson-Delmotte, V., Zhai, P., Pirani, A., Connors, S.L., Péan, C., Berger, S., Caud, N., Chen, Y., Goldfarb, L., Gomis, M.I.,Huang, M., Leitzell, K., Lonnoy, E., Matthews, J.B.R., Maycock, T.K., Waterfield, T., Yelekçi, O., Yu, R., \& Zhou, B. (eds.)]. https://www.ipcc.ch/report/ar6/wg1/downloads/report/IPCC AR6 WGI Chapter 01.p df

Clayton, D. (2021). Tropicality and the Choc en Retour of Covid-19 and Climate Change. eTropic: electronic journal of studies in the Tropics, 20(1), 54-93. https://doi.org/10.25120/etropic.20.1.2021.3787

Das, S. (2020). Climate Change, Storytelling and Sustainability: Reading Green Grass, Running Water (1993) and Son of the Thundercloud (2016). In S. Das (Ed.). Environment and Culture in the Anthropocene (pp.70-77). Authorspress.

Das, S., \& Routray, D. (2021, this issue). Climate Change and Ecocide in Sierra Leone: Representations in Aminatta Forna's Ancestor Stones and The Memory of Love. eTropic: electronic journal of studies in the Tropics, 20(2), 221-239. https://doi.org/10.25120/etropic.20.2.2021.3812

Deleuze, G. \& Guattari, F. (1980/1987). A Thousand Plateaus. (Vol. 2 of Capitalism and Schizophrenia) (B. Massumi, Trans.). University of Minnesota Press. 
D'Sousa, L. (2021). Goa: A Time That Was. An exhibition of photography. (Photographers, I. Maitra, W. X. Waswo \& V. P. Kandolkar; Curated by L. D'Sousa). Sunaparanta Goa Centre for the Arts. 8 September - 20 November.

Ghosh, A. (2016). The Great Derangement: Climate Change and the Unthinkable. University of Chicago Press. https://doi.org/10.7208/chicago/9780226323176.001.0001

Ghosh, A. (2021). The Nutmeg's Curse: Parables for a Planet in Crisis. The University of Chicago Press.

Haraway, D. (2015). Anthropocene, Capitalocene, Plantationocene, Chthulucene: Making Kin. Environmental Humanities 6, 159-165. https://doi.org/10.1215/220119193615934

Hartnett, R. (2021, this issue). Climate Imperialism: Ecocriticism, Postcolonialism, and Global Climate Change. eTropic: electronic journal of studies in the Tropics, 20(2), 138-155. https://doi.org/10.25120/etropic.20.2.2021.3809

Ingleton, S. (Director) (2020). Wild Things: A Year on the Frontline of Environmental Activism. [Documentary]. 360 Degree Films.https://www.wildthingsdocumentary.com/

IPCC (2021, In Press). Climate Change 2021: The Physical Science Basis. Contribution of Working Group I to the Sixth Assessment Report of the Intergovernmental Panel on Climate Change [Masson-Delmotte, V., P. Zhai, A. Pirani, S. L. Connors, C. Péan, S. Berger, N. Caud, Y. Chen, L. Goldfarb, M. I. Gomis, M. Huang, K. Leitzell, E. Lonnoy, J. B. R. Matthews, T. K. Maycock, T. Waterfield, O. Yelekçi, R. Yu and B. Zhou (eds.)]. Cambridge University Press.

Jerez Columbié, Y. (2021, this issue). People of the Mangrove: A Lens into Socioecological Interactions in the Ecuadorian Black Pacific. eTropic: electronic journal of studies in the Tropics, 20(2), 74-94. https://doi.org/10.25120/etropic.20.2.2021.3808

Joshi, H. (2016). Rage of the River: The Untold Story of the Kedarnath Disaster. Penguin Books.

Kandolkar, V. P. (2021, this issue). Rain in the Basilica: Protecting Goa's Bom Jesus from the Ravages of Climate Change. eTropic: electronic journal of studies in the Tropics, 20(2), 95-113. https://doi.org/10.25120/etropic.20.2.2021.3814

Kandolkar, V. P. (2021) Personal Communication, September, 6.

Kimberlain, T. B., Blake, E.S., \& Cangialosi, J.P. (2015). Hurricane Patricia. National Hurricane Center Tropical Cyclone. Rep. EP202015. www.nhc.noaa.gov/data/tcr/EP202015 Patricia.pdf.

Lacuna, I. (2014, this issue). Atmosfera Rizaliana: Metonymic Journeys of Storm Tropes in José Rizal's Writing on the Philippines. eTropic: electronic journal of studies in the Tropics, 20(2), 180-208. https://doi.org/10.25120/etropic.20.2.2021.3806

Legendre, M., Lartigue, A., Bertaux, L., Jeudy, S., Bartoli, J., Lescot, M., Alempic, J-M., Ramus, C., Bruley, C., Labadie, K., Shmakova, L., Rivkina, E., Couté, Y., Abergel, C., \& Claverie, J-M. (2015). In-depth study of Mollivirus sibericum giant virus. Proceedings of the National Academy of Sciences, 112 (38), E5327-E5335. https://doi.org/10.1073/pnas.1510795112

Lundberg, A. (2001). Being Lost at Sea: Ontology, Epistemology and a Whale Hunt. Ethnography, 2(4), 533-556. https://doi.org/10.1177/14661380122231028

Lundberg, A. (2008). Lundberg, A. (2008). Material poetics of a Malay house. The Australian Journal of Anthropology, 19(1), 1-16. https://doi.org/10.1111/j.18359310.2008.tb00102.x

Lundberg, A. (2021). Balinese Dancer wearing a Gas Mask: Climate Change and the Tropical Imaginary. [In Warren, C. \& Clayton, D. (Eds). Special Issue: Climate Change, COP26 and the Crucible of Crisis]. Scottish Geographical Journal RSGJ. 136 (1-4), 91-100. https://doi.org/10.1080/14702541.2020.1858589 
Lundberg, A., Osborne, R., Ancuta, K., \& Stasiewicz-Bieńkowska, A. (2019). Tropical Gothic: Literary and Creative Works. eTropic: electronic journal of studies in the Tropics, 18(2), 1-15. https://doi.org/10.25120/etropic.18.2.2019.3701

Marzin, C., Rahmat, R., Bernie, D., Bricheno, L., Buonomo, E., Calvert, D., Cannaby, H., Chan, S., Chattopadhyay, M., Cheong, W-K., Hassim, M.E., Gohar, L., Golding, N., Gordon, C., Gregory, J., Hein, D., Hines, A., Howard, T., Janes, T., ...Zhang, S. (2015). Singapore's Second National Climate Change Study - Phase 1. Published by Met Office, Exeter, UK; Centre for Climate Research Singapore, Singapore; National Oceanography Centre, Liverpool, UK; CSIRO, Australia; Newcastle University, UK http://ccrs.weather.gov.sg/publications-second-National-Climate-Change-StudyScience-Reports

Meillassoux, Q. (2008). After Finitude: An Essay on the Necessity of Contingency. Bloomsbury Academic. https://doi.org/10.5040/9781350252059

Nakai, S. (2021, this issue). Vernacular Knowledge, Natural Disasters, and Climate Change in Monsoon Asia. eTropic: electronic journal of studies in the Tropics, 20(2), 114-137. https://doi.org/10.25120/etropic.20.2.2021.3810

Nayar, P. K. (2017). Bhopal's Ecological Gothic: Disaster, Precarity, and the Biopolitical Uncanny. Lexington Books.

Nystrom, R.G., \& Zhang, F. (2019). Practical Uncertainties in the Limited Predictability of the Record-Breaking Intensification of Hurricane Patricia (2015). Monthly Weather Review, 147 (10), 3535-3556. https://doi.org/10.1175/MWR-D-18-0450.1

Oeven, D., \& Cabral, M. (2000). Entrevista com o Morcego [Animated Short Film]. Etnia Produções e Cinematografia.

Pezza, A.B., \& Simmonds, I. (2005). The First South Atlântic Hurricane: Unprecedented Blocking, Low Shear and Climate Change. Geophysical Research Letters, 32, (L15712), 1-5. https://doi.org/10.1029/2005GL023390

Phillipis, K. (2018, October 10) People are freaking out over this 'creepy skull' spotted in Hurricane Michael's satellite imagery. The Washington Post. https://www.washingtonpost.com/weather/2018/10/10/people-are-freaking-out-overthis-creepy-skull-spotted-hurricane-michaels-satellite-imagery/

Priest, S.(2016) Communicating Climate Change: The Path Forward. Palgrave Macmillan. https://doi.org/10.1057/978-1-137-58579-0

Revich, B. A., \& Podolnaya, M. A. (2011). Thawing of permafrost may disturb historic cattle burial grounds in East Siberia. Global health action, 4. https://doi.org/10.3402/gha.v4i0.8482

Rogers, R.F., Aberson, S., Bell, M.M., Cecil, D.J., Doyle, J.D., Kimberlain, T.B., Morgerman, J., Shay, L.K., \& Velden, C. (2017). Rewriting the Tropical Record Books: The Extraordinary Intensification of Hurricane Patricia (2015). Bulletin of the American Meteorological Society, 98, (10), 2091-2112. https://doi.org/10.1175/BAMS-D-160039.1

Roos, B. \& Hunt, A. (Eds.) (2010). Postcolonial Green: Environmental Politics and World Narratives. University of Virginia Press.

Said, E. (1978). Orientalism. Random House.

Savage, V.R. (2004), Tropicality Imagined and Experienced. Singapore Journal of Tropical Geography, 25, 26-31. https://doi.org/10.1111/j.0129-7619.2004.00170.x

Sekhsaria, P. (2017). Islands in Flux: The Andaman and Nicobar Story. Harper Litmus.

Sekhsaria, P. (2014). The Last Wave: An Island Novel. Harper Collins.

Shiva, V. (1988). Staying Alive: Women, Ecology and Survival in India. Kali for Women. Sidaway, J.D., Woon, C.Y. \& Jacobs, J.M. (2014). Planetary postcolonialism. Singapore Journal of Tropical Geography, 35, 4-21. https://doi.org/10.1111/sitg.12049 
Silva Dias, P. L., Silva Dias, M.A.F., Seluchi, M., \& Diniz, F.A. (2004). O Ciclone Catarina: Análise Preliminar da Estrutura, Dinâmica e Previsibilidade (in Portuguese). Paper Presented at XIII Brazilian Meteorological Conference, Braz. Meteorol. Soc., Fortaleza, Brazil (29 Aug. to 3 Sept.).

Simon, Z. B. (2021). A Transformação do Tempo Histórico: Temporalidades Processual e Evental. Revista de Teoria da História, 24 (1), 139-155. https://doi.org/10.5216/rth.v24i1.69676

Slovic, S. (2005). The Story of Climate Change: Science, Narrative and social Action. The Okinawan Journal of American Studies, 2, 38-42. http://ir.lib.uryukyu.ac.jp/bitstream/20.500.12000/6782/1/KJ00004187949.pdf

Slovic, S., Rangarajan, S. \& Sarveswaran, V. (Eds.) (2015). Ecocriticism of the Global South. Lexington Books.

Sodikoff, G.M. (2021, this issue). Shrunken Life: Discourses of the Cryptic and the Miniature in Madagascar. eTropic: electronic journal of studies in the Tropics, 20(2), 55-73 https://doi.org/10.25120/etropic.20.2.2021.3820

Starosielski, N. (2011). Movements that are Drawn: A History of Environmental Animation from The Lorax to FernGully to Avatar. The International Communication Gazette, 73 (1-2), 145-163. https://doi.org/10.1177/1748048510386746

Stewart, S. (1993). On Longing: Narratives of the Miniature, the Gigantic, the Souvenir, the Collection. Duke University Press. https://doi.org/10.1215/9780822378563

Thacker, E. (2011) In The Dust of This Planet: Horror of Philosophy, Vol. 1. Zero Books.

Tidman, R., Abela-Ridder, B., \& Castañeda, R.R. de. (2021). The Impact of Climate Change on Neglected Tropical Diseases: A Systematic Review. Transactions of The Royal Society of Tropical Medicine and Hygiene, 115 (2), 147-168. https://doi.org/10.1093/trstmh/traa192

Tsing, A., Deger, J., Saxena, A.K. \& Zhou, F. (2021). Feral Atlas: The More-Than-Human Anthropocene. Stanford University Press. http://doi.org/10.21627/2020fa

UWRF. (2021). 'Mulat Sarira: Self-reflection', Ubud Writers \& Readers Festival, 8 Oct-17 Oct. https://www.ubudwritersfestival.com/

Viegas, D. (Director) (2011). O Diário da Terra / Earth's Diary [Animated Short Film]. Viegas Estúdio. https://www.youtube.com/watch?v=-YfxYT7Azg0

Vital, A.V. (2018). Lapis Lazuli. Politics and Aqueous Contingency in the Animation Steven Universe. Series - International Journal of TV Serial Narratives, 4 (1), 51-62. https://doi.org/10.6092/issn.2421-454X/8401

Vital, A.V. (2020). Water, Gender, and Modern Science in the Steven Universe Animation. Feminist Media Studies, 20 (8), 1144-1158. https://doi.org/10.1080/14680777.2019.1662466

Wallace, A.R. (1869/1890). The Malay Archipelago: The land of the orang-utan, and the bird of paradise. A narrative of travel, with studies of man and nature. (Volumes I \& II). Macmillan and Co.

Warren, C. \& Clayton, D. (2020) Climate change, COP26 and the crucible of crisis: editorial introduction to the special issue, Scottish Geographical Journal, 136 (1-4),1-4, https://doi.org/10.1080/14702541.2020.1874645

Weisman, A. (2007). The World Without Us. Picador USA.

Wells, P. (1998). Understanding Animation. Routledge.

Yin, C. (2021, this issue). Goodbye on the Seas: Rising Waters, Submerging Lives. eTropic: electronic journal of studies in the Tropics, 20(2), 251-263. https://doi.org/10.25120/etropic.20.2.2021.3818

Zenteno, R. (2016, October 5). Skull image of Hurricane Matthew spooks the Internet. CNN. http://edition.cnn.com/2016/10/05/health/hurricane-matthew-skull-trnd/ 


\section{Acknowledgements}

The special issue editors thank the anonymous reviewers for their astute and helpful comments on each of the papers in this Special Issue collection. We also thank the authors who reworked and refined their papers with dedication and good humour.

Associate Professor Anita Lundberg is a cultural anthropologist. Her ethnographies - set in Bali, Singapore, Malaysia and Eastern Indonesia - explore the intertwinings of nature and culture through interdisciplinary studies of urban life, the cinematic city, neoliberal knowledge, climate change street art, the material poetics of architecture and a garden of indigenous trees, and a whale hunting village. Anita has won awards and held international fellowships: LIA TransOceanik (CNRS, JCU, Collége de France); The Cairns Institute (TCI); Evans Fellow, Cambridge University, UK; Guest Researcher, Maison Asie-Pacifique, Université de Provence, France; Visiting Fellow, Institute of the Malay World and Civilization, National University Malaysia; and Anthropologist-in-Residence, Rimbun Dahan, Malaysia. She has published extensively in academic journals, editing numerous Special Issues. Anita has curated exhibitions in NY, LA, Paris and Sydney, and her own research has been exhibited at the Australian National Maritime Museum, the National Art Gallery of Malaysia and Alliance de Française. She was a Post-Doctoral Fellow, Cambridge University, UK, she has a PhD in Anthropology, and an MA in Science \& Technology Studies.

Dr André Vasques Vital is Associate Professor in the Graduate Program in Society, Technology, and Environment (PPGSTMA) at the Evangelical University of Goiás UniEVANGELICA. He is co-editor of the book Águas no Brasil: Conflitos, Atores, e Práticas (Editora Alameda, 2019) and has published articles in important international journals such as Feminist Media Studies and ISLE: Interdisciplinary Studies in Literature and Environment. His works propose a non-humanist historical perspective, mainly through fantasy and science fiction animations, where waters and non-human animals are understood as active agents in the constitution of the past.

Dr Shruti Das is Associate Professor and Head of the Department of English and the Associate Director of the Centre for Canadian Studies, Berhampur University, India. She recently won the Prestigious ASLE Biennial Travel Award for 2019. She has written the Foreword for Crisis of Imagination, a book on Ecocriticism, published by the University of Rzeszow, Poland. She has published 11 books and over 60 research articles and creative works in National and International Journals. Her special interests are Critical Theory, Eco-criticism, South Asian Feminism, Postcolonialism, Indian Literature and Aesthetics, Linguistics and ELT. 